Marquette University

e-Publications@Marquette

$9-15-2008$

\title{
Treatability of U.S. Environmental Protection Agency Contaminant Candidate List Viruses: Removal of Coxsackievirus and Echovirus using Enhanced Coagulation
}

\author{
Brooke Mayer \\ Marquette University, Brooke.Mayer@marquette.edu \\ Hodon Ryu \\ Arizona State University at the Tempe Campus \\ Morteza Abbaszadegan \\ Arizona State University at the Tempe Campus
}

Follow this and additional works at: https://epublications.marquette.edu/civengin_fac

Part of the Civil and Environmental Engineering Commons

\section{Recommended Citation}

Mayer, Brooke; Ryu, Hodon; and Abbaszadegan, Morteza, "Treatability of U.S. Environmental Protection Agency Contaminant Candidate List Viruses: Removal of Coxsackievirus and Echovirus using Enhanced Coagulation" (2008). Civil and Environmental Engineering Faculty Research and Publications. 30.

https://epublications.marquette.edu/civengin_fac/30 


\title{
Treatability of U.S. Environmental Protection Agency Contaminant Candidate List Viruses: Removal of Coxsackievirus and Echovirus using Enhanced Coagulation
}

\author{
Brooke K. Mayer \\ Arizona State University, \\ Tempe, AZ \\ Hodon Ryu \\ Arizona State University, \\ Tempe, AZ \\ First M. Last \\ Arizona State University, \\ Tempe, $A Z$
}


NOT THE PUBLISHED VERSION; this is the author's final, peer-reviewed manuscript. The published version may be accessed by following the link in the citation at the bottom of the page.

\section{Synopsis}

The removal efficacy of the USEPA Contaminant Candidate List viruses is evaluated under enhanced coagulation conditions using varying $\mathrm{FeCl}^{3}$ doses and $\mathrm{pH}$.

\section{Abstract}

Enhanced coagulation was evaluated for removal efficacy of coxsackievirus and echovirus (Contaminant Candidate List [CCL] enteroviruses), poliovirus, four potential surrogate bacteriophages, and dissolved organic carbon (DOC). Viruses and DOC were effectively removed using enhanced coagulation, with removals generally improving as dose increased and $\mathrm{pH}$ decreased. Optimal enhanced coagulation conditions of $40 \mathrm{mg} / \mathrm{L} \mathrm{FeCl}_{3}$ and $\mathrm{pH}$ between 5 and 6.5 resulted in a maximum removal of 3.0 logs of coxsackievirus B6, 1.75 logs of echovirus 12, 2.5 logs of poliovirus $1,1.8$ logs of fr, 1.3 logs of phi-X174, 0.36 logs of MS2, 0.29 logs of PRD1, and 41\% DOC. Bacteriophages fr and phi-X174 appear to be the most representative surrogates for the physical removal of coxsackievirus, while MS2 and PRD1 are more conservative. For echovirus, MS2 and PRD1 appear to be the most appropriate surrogates. The relative removal profiles of the enteroviruses (greatest removal of coxsackievirus followed by poliovirus and then echovirus) suggest that studies of the physical removal of poliovirus may be extended to the $\mathrm{CCL}$ enteroviruses. These results contribute to evaluations of the CCL and regulatory status of coxsackievirus and echovirus and aid in building a database of the treatment efficiencies of enteroviruses and their surrogates.

\section{Introduction}

In an effort to ensure the safety of the nation's drinking water, the United States Environmental Protection Agency (USEPA) continually develops and re-evaluates regulations targeting drinking water contaminants. Recently promulgated regulations such as the Long-term 2 Enhanced Surface Water Treatment Rule (LT2) and the Disinfectants and Disinfection Byproduct Rule (DBPR) are shifting the focus of treatment processes such as coagulation in an attempt to simultaneously balance the risks posed by microbial and chemical contaminants. Strategies for mitigating contaminants of emerging concern, such as disinfection byproducts (DBPs), are specifically emphasized in these regulations. The removal of DBP precursors such as dissolved organic carbon (DOC) prior to disinfection is an effective means of limiting DBP formation. Enhanced coagulation using increased coagulant dose and/or $\mathrm{pH}$ adjustment was identified by the

Environmental Science \& Technology, Vol 42, No. 18 (September 15, 2008): pg. 6890-6896. DOI. This article is (c) American Chemical Society and permission has been granted for this version to appear in e-Publications@Marquette. American Chemical Society does not grant permission for this article to be further copied/distributed or hosted elsewhere without the express permission from American Chemical Society. 
DBPR as the best available technology for DOC removal (1). The Stage 1 DBPR requires many systems using surface water, or groundwater directly under the influence of surface water, to implement enhanced coagulation. ${ }^{2}$

Although substantial efforts have been devoted to assessing the removal of DBP precursors from drinking water using enhanced coagulation, ${ }^{1,3-5}$ limited information is available regarding the efficacy of enhanced coagulation for the removal of emerging pathogens. ${ }^{6-8}$ Conventional coagulation, flocculation, and sedimentation processes have demonstrated efficiency in the removal of viruses, bacteria, and protozoa. ${ }^{9-11}$ Similar studies are needed to evaluate the effect of enhanced coagulation optimization for the reduction of DOC on the removal of emerging pathogens, such as those on the USEPA's Contaminant Candidate List (CCL). The CCL is a list of currently unregulated contaminants warranting priority research since they are known or believed to occur in public water systems and may represent a public health risk. The current CCL (CCL 2, published in February 2005) includes four viruses: adenovirus, calicivirus, coxsackievirus, and echovirus. ${ }^{12}$ The physical removal of adenovirus and calicivirus was examined in the companion study, ${ }^{7}$ while this study focused on the removal of coxsackievirus and echovirus under enhanced coagulation conditions.

Although relatively limited data is available regarding the treatment of coxsackievirus and echovirus in drinking water systems, a great deal of information exists regarding the treatability of the prototype enterovirus, poliovirus. As the first virus propagated in tissue culture ${ }^{13}$ poliovirus is perhaps the most recognized and widely studied of all viruses. Should similarities be observed between the removal profiles of the CCL viruses and poliovirus, it may be possible to extend studies of the removal of poliovirus to coxsackievirus and echovirus. Accordingly, poliovirus was also included in this study.

In addition to the enteroviruses, bacteriophages MS2, PRD1, phi-X174, and fr were included as potential surrogates for the physical removal of coxsackievirus and echovirus. Bacteriophages share many similarities with human viruses (e.g., size, isoelectric point, etc., as shown in Table 1) but are faster, less expensive, and easier to assay 
(7). Bacteriophages having removal profiles similar to those of the CCL viruses may be valuable surrogates for studies of enterovirus removal. The results of this study will aid in building a database of treatment efficacies of enteroviruses and their surrogates and in evaluating their $\mathrm{CCL}$ and regulatory status.

Table 1. Virus Characteristics

\begin{tabular}{|c|c|c|c|c|}
\hline CCL virus & cell line & $\operatorname{size}^{a}(\mathrm{~nm})$ & $\begin{array}{c}\text { isoelectric } \\
\text { point }^{\mathrm{a}}\end{array}$ & $\begin{array}{c}\text { genetic } \\
\text { structure }\end{array}$ \\
\hline $\begin{array}{l}\text { coxsackievirus (ATCC } \\
\text { VR-155) }\end{array}$ & $\begin{array}{l}\text { buffalo green } \\
\text { monkey kidney } \\
\text { (BGM) }\end{array}$ & $24-30$ & $\mathrm{~b}$ & $\begin{array}{l}\text { Single- } \\
\text { stranded RNA }\end{array}$ \\
\hline $\begin{array}{l}\text { echovirus (ATCC VR- } \\
\text { 1563) }\end{array}$ & $\begin{array}{l}\text { buffalo green } \\
\text { monkey kidney } \\
\text { (BGM) }\end{array}$ & $24-30$ & b & $\begin{array}{l}\text { Single- } \\
\text { stranded RNA }\end{array}$ \\
\hline $\begin{array}{l}\text { poliovirus type } 1^{c} \\
\text { (strain Lsc-2ab) }\end{array}$ & $\begin{array}{l}\text { buffalo green } \\
\text { monkey kidney } \\
\text { (BGM) }\end{array}$ & $24-30$ & $\begin{array}{l}7.0-8.2(A \\
\text { state })^{d}\end{array}$ & $\begin{array}{l}\text { Single- } \\
\text { stranded RNA }\end{array}$ \\
\hline bacteriophage & bacterial host & $\operatorname{size}^{a}(n m)$ & $\begin{array}{l}\text { isoelectric } \\
\text { point }^{\mathrm{a}}\end{array}$ & $\begin{array}{l}\text { genetic } \\
\text { structure }\end{array}$ \\
\hline $\begin{array}{l}\text { MS2(ATCC 15597- } \\
\text { B1) }\end{array}$ & $\begin{array}{l}\text { Escherichia coli (ATCC } \\
\text { 15597) }\end{array}$ & $24-27$ & $3.5-3.9$ & $\begin{array}{l}\text { single- } \\
\text { stranded RNA }\end{array}$ \\
\hline $\begin{array}{l}\text { PRD1(ATCC BAA- } \\
\text { 769-B1) }\end{array}$ & $\begin{array}{l}\text { Salmonella } \\
\text { typhimurium LT2 (ATCC } \\
\text { 19585) }\end{array}$ & $62-65$ & $3.0-4.2$ & $\begin{array}{l}\text { double- } \\
\text { stranded DNA }\end{array}$ \\
\hline $\begin{array}{l}\text { phi-X174(ATCC } \\
13706-B 1)\end{array}$ & $\begin{array}{l}\text { Escherichia coli (ATCC } \\
13706 \text { ) }\end{array}$ & $23-27$ & 6.6 & $\begin{array}{l}\text { single- } \\
\text { stranded DNA }\end{array}$ \\
\hline fr(ATCC 15767-B1) & $\begin{array}{l}\text { Escherichia coli (ATCC } \\
\text { 19853) }\end{array}$ & $19-23$ & $8.9-9.0$ & $\begin{array}{l}\text { single- } \\
\text { stranded RNA }\end{array}$ \\
\hline
\end{tabular}

aAs summarized by Mayer, $2008^{6}$ and Abbaszadegan, $2007^{7}$.

betermination of the isoelectric points of pathogenic viruses is very difficult, and few have been reported. The isoelectric points of coxsackievirus and echovirus have not yet been determined by empirical means.

cPoliovirus is not a CCL virus, but it shares many similarities with coxsackievirus and echovirus, and it was included in this study for comparative purposes.

${ }^{d}$ As described by Mayer, $2008,{ }^{6}$ some enteroviruses have two conformational states (A and $B$ ), each with its own isoelectric point.

\section{Materials and Methods}

\section{Jar Testing}

A series of bench-scale jar tests was performed to optimize ferric chloride dose and $\mathrm{pH}$ with respect to DOC removal. To prevent interference between parameters, separate tests using identical 
enhanced coagulation treatments were conducted to develop removal profiles for coxsackievirus, echovirus, poliovirus, the four bacteriophages, and DOC. Untreated central Arizona surface water of turbidity 9-22 NTU, pH 7-8, alkalinity 140-260 mg/L as $\mathrm{CaCO}_{3}$, and DOC $4 \mathrm{mg} / \mathrm{L}$ was used. A $10 \mathrm{~L}$ water sample (at $20^{\circ} \mathrm{C}$ ) was seeded with a known number of viruses (final concentration of $10^{6}$ plaque forming units [PFU] per $\mathrm{mL}$ of each bacteriophage or $10^{3.5} 50 \%$ tissue culture infectious dose [TCID 50 ] per $\mathrm{mL}$ of each enterovirus). A sample of the seeded water was collected for determination of initial virus concentrations. The water was distributed to a Phipps \& Bird PB-700 (Richmond, VA) jar test apparatus at a volume of $1.5 \mathrm{~L}$ per jar. Ferric chloride (ferric chloride hexahydrate lumps, Sigma Chemical Co., St. Louis, MO), cationic polymer (polydiallyldimethyl ammonium chloride [polyDADMAC], Clarifloc 350, Polydyne, Inc., Riceboro, GA), and $1 \mathrm{~N}$ $\mathrm{HCl}$ were immediately added, as described in the following paragraph.

Ferric chloride was used in this study because it has demonstrated improved organic removal compared to alum. ${ }^{14}$ Doses are heavily dependent on water quality, and are therefore widely variable. ${ }^{15}$ Enhanced coagulation doses range from 5 to $150 \mathrm{mg} / \mathrm{L}$ $\mathrm{FeCl}_{3},{ }^{14}$ but more commonly range from 20 to $60 \mathrm{mg} / \mathrm{L} \mathrm{FeCl}_{3} .{ }^{4}$ In this study, coagulant doses ranging from 20 to $120 \mathrm{mg} / \mathrm{L} \mathrm{FeCl}_{3}$ were tested in increments of $20 \mathrm{mg} / \mathrm{L}$ in an effort to optimize coagulant dose. Variations in polymer dose have not demonstrated a significant effect on DOC removal during enhanced coagulation; ${ }^{1}$ therefore, polymer was applied at a constant dose of $0.4 \mathrm{mg} / \mathrm{L}$. At the previously determined optimal coagulant dose, $\mathrm{pH}$ adjustment was evaluated in order to identify the optimal $\mathrm{pH}$. Coagulation of natural organic matter with ferric chloride is typically optimized at a $\mathrm{pH}$ of approximately $4-5 ;{ }^{3,5}$ however, for practical reasons, enhanced coagulation is generally carried out in a $\mathrm{pH}$ range of $5-7 .{ }^{1}$ At the optimal coagulant dose, target $\mathrm{pH}$ values ranging from 5.5 to 7.0 were tested using increments of 0.5 as part of this investigation.

Immediately following chemical addition, the jars were mixed at $100 \mathrm{rpm}$ for $1 \mathrm{~min}, 40 \mathrm{rpm}$ for $10 \mathrm{~min}, 20 \mathrm{rpm}$ for $10 \mathrm{~min}$, and no mixing for $30 \mathrm{~min}$, as described by Volk et al. ${ }^{4}$ Samples were assayed for bacteriophages or enteroviruses, $\mathrm{DOC}, \mathrm{pH}$, turbidity, and ultraviolet 
absorbance at a wavelength of $254 \mathrm{~nm}\left(\mathrm{UV}_{254}\right)$, all of which have the potential to affect the efficacy of coagulation.

\section{Virus Propagation and Assays}

Bacteriophages MS2 (ATCC 15597-B1), phi-X174 (ATCC 13706B1), fr (ATCC 15767-B1), and PRD1 (ATCC BAA-769-B1) and their respective bacterial hosts $E$. coli (ATCC 15597, 13706, and 19853) and S. typhimurium LT2 (ATCC 19585) were obtained from the American Type Culture Collection (ATCC, Rockville, MD). Bacteriophage stocks were propagated using the double agar layer (DAL) method. ${ }^{16}$ The bacteriophages were eluted from the plates using $10 \mathrm{~mL}$ of buffered demand free (BDF) water $\left(0.54 \mathrm{~g} \mathrm{Na}_{2} \mathrm{HPO}_{4}\right.$ and $0.88 \mathrm{~g} \mathrm{KH}_{2} \mathrm{PO}_{4}$ per liter of nanopure water, $\mathrm{pH} 7.0)$. The supernatant was collected and centrifuged at $4^{\circ} \mathrm{C}$ at $1200 \mathrm{~g}$ for $15 \mathrm{~min}$ to remove bacteria. To minimize DOC content, the stocks were purified using two successive polyethylene glycol (PEG) precipitations followed by a Vertrel XF (Micro Care Marketing Services, New Britain, CT) extraction and resuspension in BDF, as described by Thurston-Enriquez et al. ${ }^{17}$ Briefly, the suspension was augmented with 9\% PEG (MW 8000) and $1 \mathrm{M} \mathrm{NaCl}$ and was allowed to stir overnight at $4{ }^{\circ} \mathrm{C}$. It was then centrifuged at $4{ }^{\circ} \mathrm{C}$ at $8000 \mathrm{~g}$ for $90 \mathrm{~min}$. The supernatant was discarded, and the pellet was resuspended in $10 \%$ of its original volume of BDF water. To remove lipids and facilitate the monodispersion of viruses, a Vertrel XF extraction was performed by centrifuging a suspension of equal parts Vertrel and virus at $4{ }^{\circ} \mathrm{C}$ at $8000 \mathrm{~g}$ for $90 \mathrm{~min} .{ }^{17}$ The supernatant containing the purified viruses (typically on the order of $10^{10} \mathrm{PFU} / \mathrm{mL}$ ) was stored at $4^{\circ} \mathrm{C}$.

Coxsackievirus B6 Schmitt (ATCC VR-155) and echovirus 12 Travis (ATCC VR-1563) were obtained from the ATCC. Poliovirus type 1 (attenuated strain Lsc-2ab) was kindly provided by Dr. Charles P. Gerba of the University of Arizona. All viruses were cultured using conventional in vitro cell culture techniques in a continuous buffalo green monkey kidney (BGM) cell line in 1X Eagle's minimum essential medium (MEM) containing 5\% fetal bovine serum (FBS). For virus propagation, the cells were inoculated with approximately $1 \times 10^{6}$ $\mathrm{TCID}_{50} / \mathrm{mL}$ of virus and incubated at $37{ }^{\circ} \mathrm{C}$ until at least $90 \%$ infected. Three freeze/thaw cycles were used to facilitate the release of the 
virus particles. The supernatant was collected and centrifuged at $4{ }^{\circ} \mathrm{C}$ at $1200 \mathrm{~g}$ for $15 \mathrm{~min}$ to remove cellular debris. Virus stocks were purified using two successive PEG precipitations, a Vertrel XF extraction, and resuspension in BDF water, as described previously. The purified viruses (typically on the order of $10^{6} \mathrm{TCID}_{50} / \mathrm{mL}$ ) were stored at $\times 80^{\circ} \mathrm{C}$.

Immediately following jar test experiments, the water samples were serially diluted (10-fold) in BDF water (sufficient for up to 5-log removal of bacteriophages and 3.5-log removal of enteroviruses). The bacteriophages were assayed in triplicate using the DAL method, ${ }^{16}$ and the enteroviruses were assayed using conventional in vitro cell culture techniques. Positive and negative controls were included in each set of assays. For cell culture, BGM cells were grown in 24-well trays. Each sample dilution was used to inoculate four wells, using $0.1 \mathrm{~mL}$ of sample per well. The trays were incubated in a $5 \% \mathrm{CO}_{2}$ incubator at $37^{\circ} \mathrm{C}$ and were examined daily for up to 14 days for cytopathogenic effects (CPE) in the form of cell enlargement, rounding, and detachment. The Karber TCID 50 method was used to quantify the viral concentration of each sample, as described by Abbaszadegan et al. ${ }^{7}$ The log reduction of bacteriophages and enteroviruses $\left(-\log \left[N_{\mathrm{t}} / N_{0}\right]\right.$, where $N_{\mathrm{t}}$ is the number of viruses in the treated sample and $N_{0}$ is the number in the original sample) was calculated for each enhanced coagulation treatment condition.

\section{Chemical Parameter Analysis}

The $\mathrm{pH}$ was measured using a Mettler (Columbus, $\mathrm{OH}$ ) $\mathrm{pH}$ meter. Turbidity was measured using a Hach (Loveland, $\mathrm{CO}$ ) model 2100P turbidimeter. For DOC determination, samples were filtered using $1.2 \mu \mathrm{m}$ Whatman (Middlesex, UK) GF/C glass microfiber filters, acidified using $1 \mathrm{~N} \mathrm{HCl}$, and analyzed using a Shimadzu 5050A (Kyoto, Japan) total organic carbon analyzer. A Shimadzu Multispec 1501 was used to measure $U_{254}$. $U_{254}$ was used to calculate specific UV absorbance $\left(\right.$ SUVA $\left.=\mathrm{UV}_{254} / \mathrm{DOC},\left[\mathrm{L}(\mathrm{mg} \times \mathrm{m})^{-1}\right]\right)$, which is sometimes used as a surrogate measurement of DBP precursors. ${ }^{14}$ 
NOT THE PUBLISHED VERSION; this is the author's final, peer-reviewed manuscript. The published version may be accessed by following the link in the citation at the bottom of the page.

\section{Statistical Analysis}

Statistical analyses were performed to determine if the mean bacteriophage removals resulting from different treatment conditions were statistically different at a significance level of $a=0.05$. SPSS (Chicago, IL) Version 12.0 statistical software was used to compute the Levene statistic, analysis of variance (ANOVA), Welch test, Tukey's honestly significant difference (HSD) test, and the Games-Howell test, as described by Abbaszadegan et al. ${ }^{7}$ Statistics were also used to test for correlations between virus removals and their respective isoelectric points and sizes. Using Microsoft Excel, Pearson product moment correlations (as described by Karl Pearson in 1895) ${ }^{18}$ and linear regression models were computed and used to evaluate the relationship between the variables.

\section{Results and Discussion}

\section{Coagulant Dose Optimization Jar Tests}

The coagulant dose optimization jar tests (performed without $\mathrm{pH}$ adjustment) demonstrated that bacteriophage removal generally increased as coagulant dose increased (Figure 1). Overall, fr was removed to the greatest extent, followed by phi-X174, PRD1, and MS2. Statistical analyses were performed using the mean log removals of the bacteriophages $(n=3)$ at different coagulant doses to determine the optimal dose required to produce significant virus removal. For each of the four bacteriophages, there was a significant difference between log removals at different coagulant doses $(P \leq$ $0.05)$, as shown in Table 1 in the Supporting Information. The optimal dose for the removal of each bacteriophage (as summarized in Table 2) was identified as the lowest dose at which a significant improvement in removal was observed with incremental increases in coagulant dose $(P \leq 0.05)$, but beyond which, removals did not significantly improve. The results of the statistical analyses are provided in Table 2 in the Supporting Information. 
NOT THE PUBLISHED VERSION; this is the author's final, peer-reviewed manuscript. The published version may be accessed by following the link in the citation at the bottom of the page.

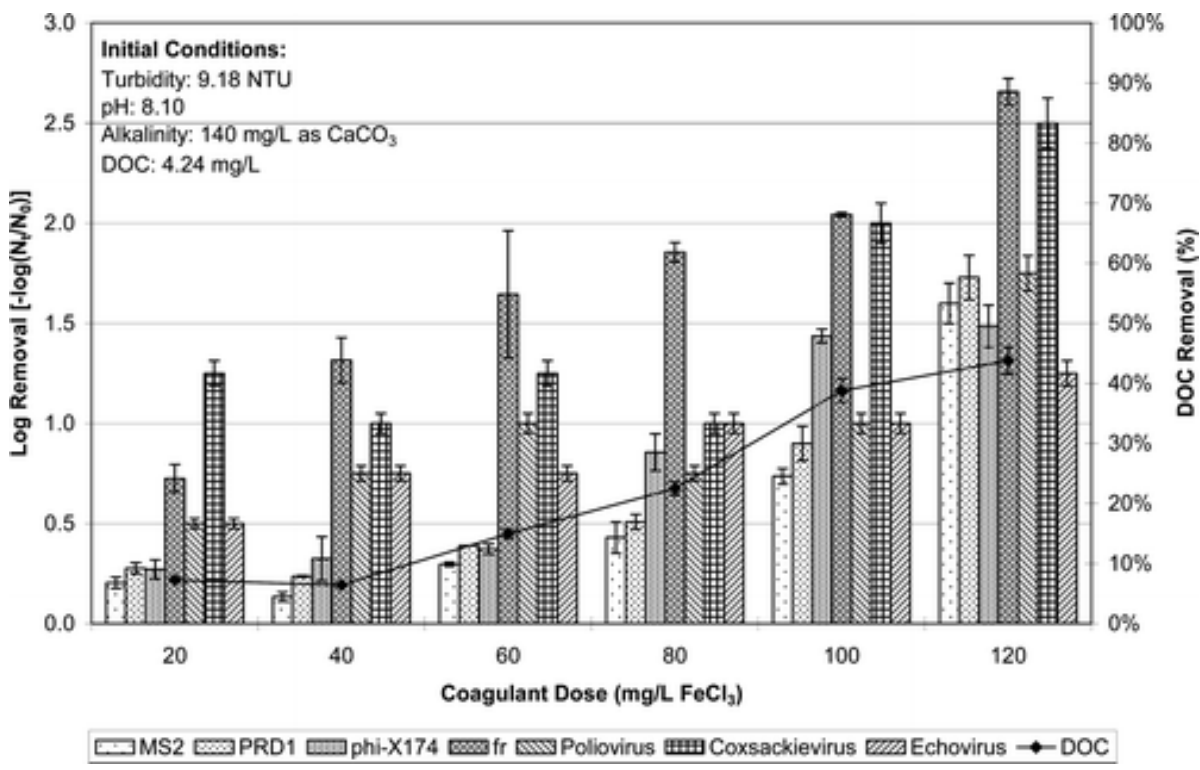

Figure 1. Removal of microbes and $\mathrm{DOC}$ as a function of $\mathrm{FeCl}_{3}$ dose in the first jar test. The error bars represent \pm 1 standard deviation for the bacteriophages and $\pm 5 \%$ for the enteroviruses and DOC.

Table 2. Summary of Optimal Treatment Conditions

variable

MS2

PRD1

phi-X174

$\mathrm{fr}$

coxsackievirus

echovirus

poliovirus

DOC

overall

recommendation coagulant dose $\left(\mathrm{mg} / \mathrm{L} \mathrm{FeCl}_{3}\right) \quad \mathrm{pH}\left(\right.$ at $\left.40 \mathrm{mg} / \mathrm{L} \mathrm{FeCl}_{3}\right)$

60 $<6.5$

$\geq 100$

$100 \quad 6.0$

$40<6.5$

$100-120$ (first test); 60 (2nd test) $<6.5$

(1st test) $;<6.0$ (2nd test)

120 (1st test); 60 (2nd test) $\quad<7.0$ (1st test) $;<6.0$ (2nd test)

120 (1st test); 60 (2nd test) $\quad<5.5$

100 (1st test); 60 (2nd test) $\quad<6.5$

$40<6.5$

Due to the time- and material-intensive nature of the in vitro cell culture assay, one replicate was analyzed for each of the two independent enterovirus experiments. Since water quality varied between tests, they were not considered replicates, and statistical analyses were not employed to determine the optimal coagulant dose for enterovirus removal. However, the data in Figure 1 (for the first virus test) indicate that although some improvement in enterovirus removal was observed at low coagulant doses, consistent improvements were achieved only at the high end of the dose range. Based on the results of the first test, a second enterovirus jar test was

Environmental Science \& Technology, Vol 42, No. 18 (September 15, 2008): pg. 6890-6896. DOI. This article is (C) American Chemical Society and permission has been granted for this version to appear in e-Publications@Marquette. American Chemical Society does not grant permission for this article to be further copied/distributed or hosted elsewhere without the express permission from American Chemical Society. 
performed, thereby providing a second independent data set. For the second test, the coagulant dose range was narrowed to 20,40, and 60 $\mathrm{mg} / \mathrm{L} \mathrm{FeCl}_{3}$, based on improved performance and practicality under these conditions, as indicated by the results of the bacteriophage and first CCL virus test results. The results of the second test are shown in Figure 2. Again, they suggest that enterovirus removal improves throughout the dose range tested. Relative to one another, coxsackievirus B6 (CoxB6) was consistently removed to the greatest extent, followed by poliovirus 1 (Polio1), and then echovirus 12 (Echo12).

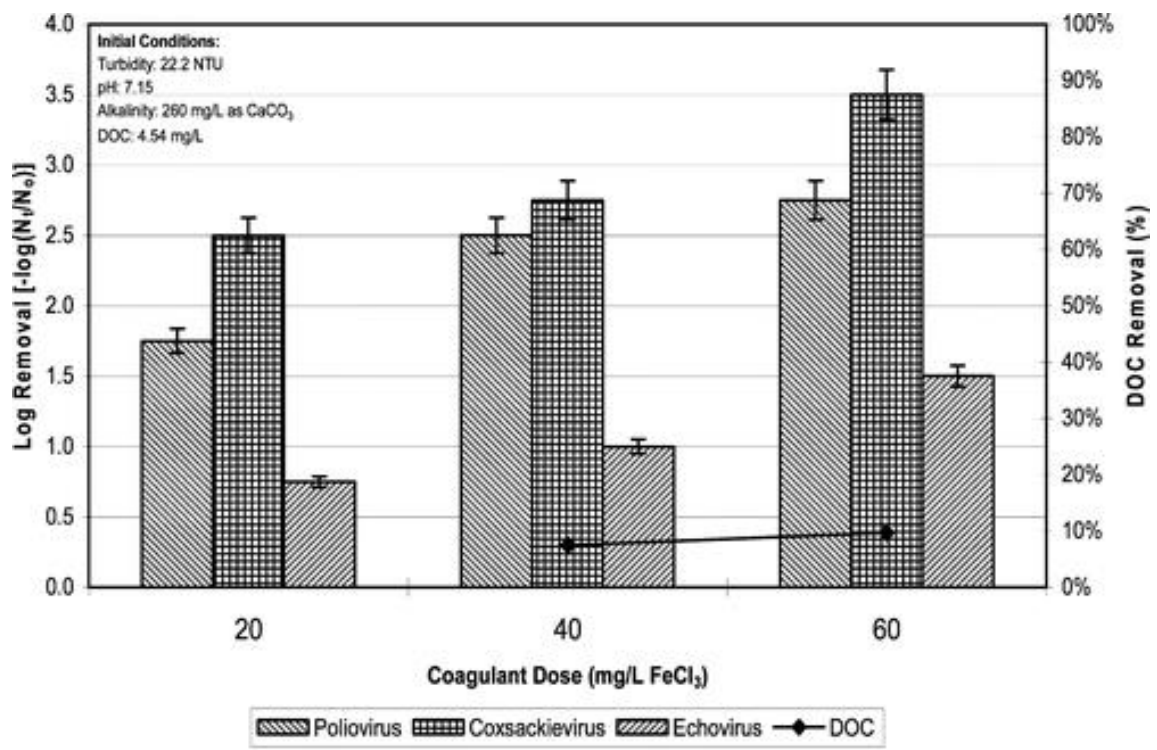

Figure 2. Removal of microbes and $\mathrm{DOC}$ as a function of $\mathrm{FeCl}_{3}$ dose in the second jar test. The error bars represent $\pm 5 \%$.

CoxB6 was consistently removed to a greater extent than phi$\mathrm{X} 174$, PRD1, and MS2. This suggests that these microbes may be acceptable surrogates for CoxB6 since the treatment required for their removal would remove CoxB6 to an even greater extent. The removal of phi-X174 was more similar to that of CoxB6, suggesting that phiX174 would be more representative, while MS2 and PRD1 would be more conservative surrogates since they were removed to a lesser extent. The removal profile of bacteriophage fr was most similar to CoxB6; however, its suitability as a surrogate was questionable since it was sometimes removed more efficiently than CoxB6. Echo12 was consistently removed to a lesser extent than CoxB6, and was also generally removed to a lesser extent than bacteriophages fr and phi-

Environmental Science \& Technology, Vol 42, No. 18 (September 15, 2008): pg. 6890-6896. DOI. This article is (c) American Chemical Society and permission has been granted for this version to appear in e-Publications@Marquette. American Chemical Society does not grant permission for this article to be further copied/distributed or hosted elsewhere without the express permission from American Chemical Society. 
X174. This indicates that fr and phi-X174 would not be suitable surrogates, while MS2 and PRD1 may be appropriate surrogates since they were removed to a similar, but lesser extent than Echo12.

Coagulation processes typically target the removal of organic matter, such as DOC, whereas virus removal is considered an ancillary benefit. Accordingly, optimal coagulant doses are generally selected on the basis of DOC removal, regardless of the optimal dose range for virus removal. The USEPA's Enhanced Coagulation Guidance Manual ${ }^{2}$ requires a $25 \%$ reduction in DOC to satisfy the enhanced coagulation requirements for this source water (total organic carbon of 4.0-8.0 $\mathrm{mg} / \mathrm{L}$ and alkalinity $>120 \mathrm{mg} / \mathrm{L}$ as $\mathrm{CaCO}_{3}$ ). This condition was satisfied using doses of $100-120 \mathrm{mg} / \mathrm{L} \mathrm{FeCl}_{3}$ (Table 3 ). In this range, substantial decreases in turbidity, $U_{254}$, and SUVA (all measures of the efficacy of coagulation) were also observed. For enhanced coagulation, the optimal coagulant dose is defined as the point of diminishing return (PODR). ${ }^{2}$ The PODR is the dose at which the change in DOC removal divided by the change in coagulant addition drops to (and subsequently remains below) $0.03 .{ }^{2}$ Using the PODR criteria, the optimal dose for DOC removal was $100 \mathrm{mg} / \mathrm{L} \mathrm{FeCl}_{3}$ in the first test and $60 \mathrm{mg} / \mathrm{L} \mathrm{FeCl}_{3}$ in the second test. These doses exceed those typically used at water treatment facilities, but can be reduced using $\mathrm{pH}$ adjustment to improve DOC removal. Consequently, $\mathrm{pH}$ optimization tests were performed using a more moderate coagulant dose of 40 $\mathrm{mg} / \mathrm{L} \mathrm{FeCl}_{3}$ and $\mathrm{pH}$ adjustment, as described in the following section.

Table 3. Chemical Parameters for Jar Tests

\begin{tabular}{|c|c|c|c|c|c|c|c|}
\hline \multirow[t]{2}{*}{$\begin{array}{c}\mathrm{FeCl}_{3} \mathrm{dose} \\
(\mathrm{mg} / \mathrm{L})\end{array}$} & pH & $\begin{array}{c}\text { DOC } \\
(\mathrm{mg} / \mathrm{L})\end{array}$ & $\begin{array}{c}\text { DOC\% } \\
\text { removal) }\end{array}$ & $\begin{array}{c}\Delta \\
\text { doc/ } \\
\text { dose }\end{array}$ & $\begin{array}{l}\text { turbidity } \\
\text { (NTU) }\end{array}$ & $\begin{array}{l}U_{254} \\
\left(\mathrm{~cm}^{-1}\right)\end{array}$ & \\
\hline & \multicolumn{7}{|c|}{ bacteriophage and first CCL virus jar test } \\
\hline 0 & 8.10 & 4.24 & & & 9.18 & 0.090 & 2.1 \\
\hline 20 & 7.04 & 3.93 & $7.3 \%$ & 0.02 & 1.87 & 0.061 & 1.6 \\
\hline 40 & 6.92 & 3.97 & $6.4 \%$ & 0.00 & 2.04 & 0.044 & 1.1 \\
\hline 60 & 6.51 & 3.61 & $14.9 \%$ & 0.02 & 1.24 & 0.032 & 0.9 \\
\hline 80 & 6.35 & 3.29 & $22.4 \%$ & 0.02 & 1.18 & 0.027 & 0.8 \\
\hline 100 & 6.11 & 2.60 & $38.7 \%$ & 0.03 & 1.61 & 0.021 & 0.8 \\
\hline 120 & 6.03 & 2.38 & $43.9 \%$ & 0.01 & 1.27 & 0.018 & 0.8 \\
\hline 40 & 7.0 & 3.97 & $6.4 \%$ & & 0.61 & 0.044 & 1.1 \\
\hline 40 & 6.5 & 3.50 & $17.5 \%$ & & 0.65 & 0.042 & 1.2 \\
\hline 40 & 6.0 & 2.76 & $34.9 \%$ & & 0.71 & 0.033 & 1.2 \\
\hline
\end{tabular}

Environmental Science \& Technology, Vol 42, No. 18 (September 15, 2008): pg. 6890-6896. DOI. This article is (c) American Chemical Society and permission has been granted for this version to appear in e-Publications@Marquette. American Chemical Society does not grant permission for this article to be further copied/distributed or hosted elsewhere without the express permission from American Chemical Society. 


\begin{tabular}{|c|c|c|c|c|c|c|c|}
\hline $\begin{array}{c}\mathrm{FeCl}_{3} \text { dose } \\
(\mathrm{mg} / \mathrm{L})\end{array}$ & $\mathbf{p H}$ & $\begin{array}{c}\text { DOC } \\
(\mathrm{mg} / \mathrm{L})\end{array}$ & $\begin{array}{l}\text { DOC\% } \\
\text { removal) }\end{array}$ & $\begin{array}{c}\Delta \\
\text { Doc/ } \\
\text { dose }\end{array}$ & $\begin{array}{l}\text { turbidity } \\
\text { (NTU) }\end{array}$ & $\begin{array}{l}U_{254} \\
\left(\mathrm{~cm}^{-1}\right)\end{array}$ & $\begin{array}{c}\underset{\text { SUVA }}{(\mathrm{L} /(\mathrm{mg}} \times \\
\mathrm{m}))\end{array}$ \\
\hline 40 & 5.5 & 2.49 & $41.3 \%$ & & 0.73 & 0.025 & 1.0 \\
\hline \multicolumn{8}{|c|}{ second CCL virus jar test } \\
\hline 0 & 7.15 & 4.54 & & & 22.2 & 0.075 & 1.6 \\
\hline 20 & 6.82 & & & & 2.83 & 0.063 & \\
\hline 40 & 6.53 & 4.20 & $7.5 \%$ & & 1.43 & 0.047 & 1.1 \\
\hline 60 & 6.28 & 4.10 & $9.7 \%$ & 0.01 & 1.04 & 0.040 & 1.0 \\
\hline 40 & 6.0 & 3.46 & $7.5 \%$ & & 1.43 & 0.047 & 1.1 \\
\hline 40 & 5.5 & 3.45 & $24.0 \%$ & & 0.69 & 0.030 & 0.9 \\
\hline
\end{tabular}

For the $\mathrm{pH}$ optimization jar tests (as in the dose adjustment jar tests), bacteriophage fr was generally removed to the greatest extent, followed by phi-X174, MS2, and PRD1 (Figure 3). Overall, bacteriophage removal improved slightly in response to reductions in $\mathrm{pH}$. The removals of MS2, phi-X174, and $\mathrm{fr}$ demonstrated significant improvement as $\mathrm{pH}$ incrementally decreased from 8.0 to 5.5 ( $P \leq$ 0.05 ), whereas PRD1 removal did not improve significantly (Table 3 in the Supporting Information). Statistical analyses were performed using the mean log removals of the bacteriophages at different $\mathrm{pH}$ values to determine the optimal $\mathrm{pH}$ required to produce significant virus removal. The optimal $\mathrm{pH}$ (as summarized in Table 2) was identified as the highest $\mathrm{pH}$ at which significant improvement in removal was observed as $\mathrm{pH}$ decreased, but beyond which, significant improvements were not observed. The results of the statistical analyses are provided in Table 4 in the Supporting Information. 
NOT THE PUBLISHED VERSION; this is the author's final, peer-reviewed manuscript. The published version may be accessed by following the link in the citation at the bottom of the page.

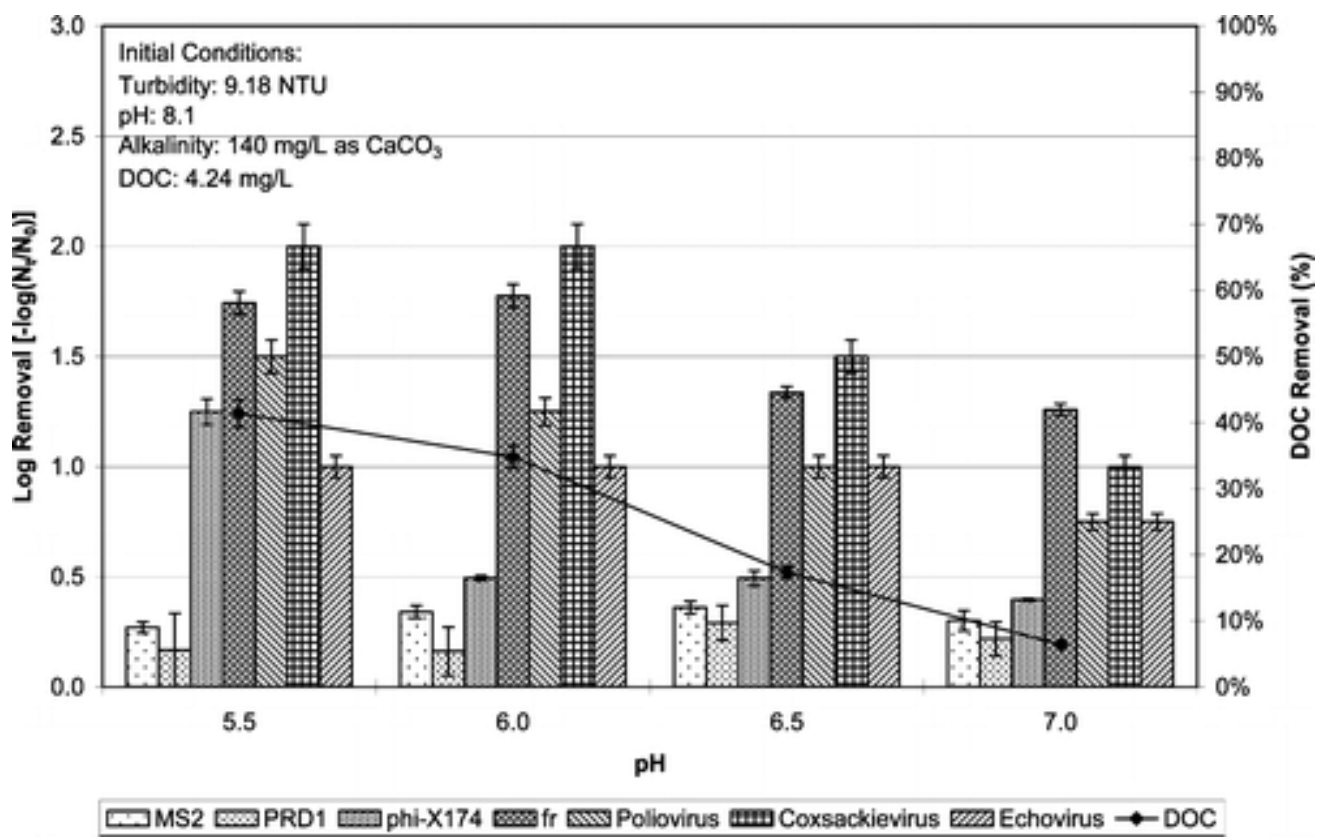

Figure 3. Removal of microbes and $\mathrm{DOC}$ as a function of $\mathrm{pH}$ adjustment at a coagulant dose of $40 \mathrm{mg} / \mathrm{L} \mathrm{FeCl}_{3}$ in the first jar test. The error bars represent \pm 1 standard deviation for the bacteriophages and $\pm 5 \%$ for the $C C L$ viruses and DOC removals.

Figures 3 and 4 illustrate that enterovirus removals generally improved as the $\mathrm{pH}$ decreased, although statistical analyses could not be employed to verify this observation, as described previously. For the first virus test (Figure 3), the removal of CoxB6 improved as the $\mathrm{pH}$ decreased from 7.0 to 6.5 , and again as $\mathrm{pH}$ decreased to 6.0. No additional removal was observed when the $\mathrm{pH}$ was decreased to 5.5, thereby suggesting an optimal pH for CoxB6 removal of less than 6.5. For Echo12, no additional removal was observed for $\mathrm{pH}$ adjustments below 6.5 , thereby indicating that $\mathrm{pH}$ values less than 7.0 were optimal. The removal of Polio1 appeared to improve with each incremental reduction in $\mathrm{pH}$. Based on these results, a second virus test was performed at $\mathrm{pH}$ values of $6.5,6.0$, and 5.5 (Figure 4). The second test again suggested that virus removal improved as the $\mathrm{pH}$ decreased. As in the dose optimization tests, CoxB6 was removed to a greater extent than Polio1, followed by Echo12. The consistency of the relative removal profiles of the enteroviruses suggests that studies of the physical removal of poliovirus may be extended to the $\mathrm{CCL}$ enteroviruses, which may contribute to evaluations of their $\mathrm{CCL}$ and regulatory status.

Environmental Science \& Technology, Vol 42, No. 18 (September 15, 2008): pg. 6890-6896. DOI. This article is (C American Chemical Society and permission has been granted for this version to appear in e-Publications@Marquette. American Chemical Society does not grant permission for this article to be further copied/distributed or hosted elsewhere without the express permission from American Chemical Society. 
NOT THE PUBLISHED VERSION; this is the author's final, peer-reviewed manuscript. The published version may be accessed by following the link in the citation at the bottom of the page.

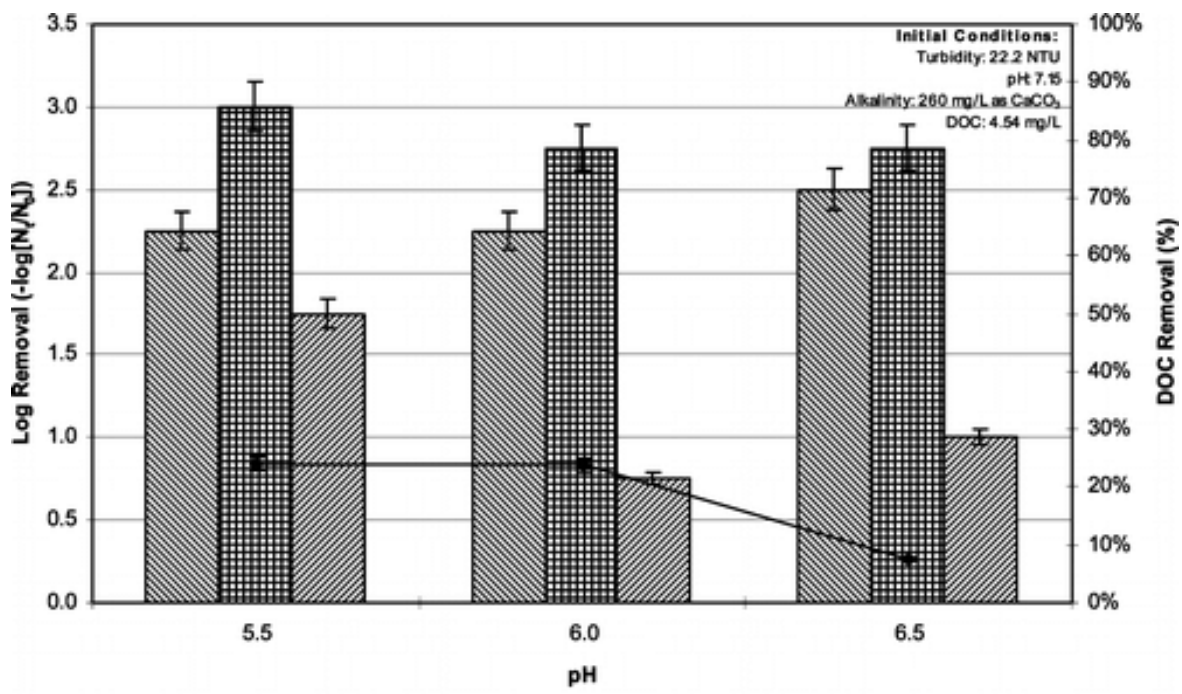

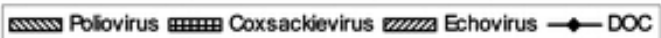

Figure 4. Removal of microbes and $\mathrm{DOC}$ as a function of $\mathrm{pH}$ adjustment at a coagulant dose of $40 \mathrm{mg} / \mathrm{L} \mathrm{FeCl}_{3}$ in the second jar test. The error bars represent $\pm 5 \%$.

CoxB6 was consistently removed to a greater extent than bacteriophages phi-X174, PRD1, and MS2, and also exceeded $\mathrm{fr}$ throughout most of the $\mathrm{pH}$ range tested. This suggests that the bacteriophages may be acceptable surrogates for CoxB6. The removals of fr and phi-X174 were the most similar to CoxB6, suggesting that they would be more representative surrogates, whereas MS2 and PRD1 would be more conservative surrogates since they were removed to a lesser extent. Echo12 was consistently removed to a lesser extent than CoxB6. It was also removed to a lesser extent than bacteriophage $\mathrm{fr}$, indicating that fr would not be a suitable surrogate. Although Echo12 was removed to a greater extent than phi-X174 for most of the $\mathrm{pH}$ range, phi-X174 was removed to a greater extent at $\mathrm{pH} 5.5$. Thus, the suitability of phi-X174 as a surrogate for Echo12 was questionable. Regardless, MS2 and PRD1 were consistently removed to a lesser extent than Echo12, thereby indicating that they may be appropriate surrogates.

The $\mathrm{pH}$ optimization jar tests satisfied the USEPA enhanced coagulation guidelines ${ }^{2}$ by achieving at least 25\% DOC removal below $\mathrm{pH} 6.5$ in the first test (Table 3). Decreases in $\mathrm{pH}$ also resulted in decreases in $U_{254}$ and SUVA. Although an optimal $\mathrm{pH}$ cannot be determined using the PODR calculation, as done to optimize dose (since the PODR is calculated relative to coagulant dose increments),

Environmental Science \& Technology, Vol 42, No. 18 (September 15, 2008): pg. 6890-6896. DOI. This article is (C American Chemical Society and permission has been granted for this version to appear in e-Publications@Marquette. American Chemical Society does not grant permission for this article to be further copied/distributed or hosted elsewhere without the express permission from American Chemical Society. 
the data suggests that the optimal $\mathrm{pH}$ range is less than 6.5 based on improved $\mathrm{DOC}$ removal in this $\mathrm{pH}$ range. Practical limitations effectively impart a lower $\mathrm{pH}$ boundary of $5 ;^{3}$ thus, the optimal $\mathrm{pH}$ range for DOC removal was 5.0-6.5.

\section{Virus Removal Mechanisms}

The quantification of virus removal during physical and chemical separation processes is well documented. ${ }^{19-21}$ The main mechanism for the physical removal of viruses appears to be adsorption and charge neutralization followed by gravitational separation; however, the details of virus adsorption during coagulation and flocculation are not yet fully understood. Studies of transport through soil matrices have reported that the adsorption of viruses is a complex process in which hydrophobicity, surface charge, and isoelectric point (pI) are influential factors. ${ }^{22,23}$ While it appears that no individual factor can adequately explain the mechanism of virus adsorption, pI has been suggested to be the dominant factor controlling virus adsorption during transport through sandy soils. ${ }^{22}$ The complete effects of the addition of coagulant, specifically on the surface charge of the virus, are not fully understood, but the pI may help to explain adsorption during coagulation.

The $\mathrm{pI}$ of fr is relatively high (Table 1 ), meaning that its surface is positively charged in $\mathrm{pH}$ ranges encountered during coagulation (58), whereas MS2 and PRD1 would be negatively charged and phi-X174 may be either. For negatively charged particulate matter, the bacteriophage pIs generally support the observed removal trend ( $\mathrm{fr}>$ phi-x174 > PRD1 > MS2). The relatively high stability (low physical removal) of MS2 is consistent with previous studies of filtration. ${ }^{24}$ Relative to the other viruses, the $\mathrm{pI}$ of poliovirus is more similar to $\mathrm{fr}$, perhaps suggesting that poliovirus removal would more closely resemble fr removal compared to the other bacteriophages. This hypothesis appears to be supported by the data shown in Figures 1 and 3. Pearson correlation coefficients and linear regression models were used to evaluate the linear relationship between virus removal and their respective pIs and sizes (averages from Table 1). The statistics were computed separately for each treatment condition (jar test, coagulant dose/pH tested) to eliminate extraneous factors that 
would affect microbial removal other than their physical characteristics. This essentially "leveled the field" so that the relationship between the variables was evaluated for a given water matrix and level of treatment. The results (Table 5 in the Supporting Information) indicated that virus removal was strongly correlated to isoelectric point $\left(-0.05<\right.$ Pearson $<0.05^{25}$ and $\left.R^{2}>0.80\right)$, but the relationship between virus removal and size was not nearly as strong. Thus, while the exact mechanisms of adsorption cannot be identified as a result of this study, the results suggest that pI plays a role in virus removal by adsorption.

\section{Summary}

At a coagulant dose of $40 \mathrm{mg} / \mathrm{L} \mathrm{FeCl}_{3}$ and a $\mathrm{pH}$ below 6.5, the USEPA criteria was satisfied by removing more than $25 \%$ of DOC. Under these enhanced coagulation conditions, a maximum removal of 3.0 logs of CoxB6, 1.75 log of Echo12, 2.5 logs of Polio1, 1.8 logs of $\mathrm{fr}$, 1.3 logs of phi-X174, 0.36 logs of MS2, 0.29 logs of PRD1, and $41 \%$ DOC was observed. Viral isoelectric points appear to heavily influence the efficacy of removal by coagulation processes. Overall, CoxB6 was removed more efficiently than the bacteriophages, indicating that they may be suitable surrogates, with fr and phi-X174 being more representative and MS2 and PRD1 being more conservative. Bacteriophages MS2 and PRD1 appear to be the most suitable surrogates for Echo12. The relative removal profiles of the enteroviruses (greatest removal of coxsackievirus followed by poliovirus and then echovirus) suggest that studies of the physical removal of poliovirus may be extended to the CCL enteroviruses, which may contribute to evaluations of their CCL and regulatory status.

\section{Acknowledgment}

This work was supported by the National Science Foundation (NSF) Water Quality Center at Arizona State University. Brooke Mayer was on appointment under the Department of Homeland Security Scholarship and Fellowship Program. All opinions are the authors' and do not necessarily reflect the policies and views of NSF or DHS. The mention of product names does not constitute endorsement of the company. 
NOT THE PUBLISHED VERSION; this is the author's final, peer-reviewed manuscript. The published version may be accessed by following the link in the citation at the bottom of the page.

\section{Supporting Information}

The summary tables of the statistical analyses. This material is available free of charge via the Internet at http://pubs.acs.org.

\section{References}

${ }^{1}$ Kastl, G.; Sathasivan, A.; Fisher, I.; van Leewen, J. Modeling DOC removal by enhanced coagulation J. Am. Water Works Assoc. 2004, 96, 79-89

2USEPA. Enhanced Coagulation and Enhanced Precipitative Softening Guidance Manual; United States Environmental Protection Agency: Cincinnati, OH, 1999.

${ }^{3}$ Childress, A. E.; Vrijenhoek, E. M.; Elimelech, M.; Tanaka, T. S.; Beuhler, M. D. Particulate and THM precursor removal with ferric chloride $J$. Environ. Eng. 1999, 125, 1054-1061

${ }^{4}$ Volk, C.; Bell, K.; Ibrahim, E.; Verges, D.; Amy, G.; Lechevallier, M. Impact of enhanced and optimized coagulation on removal of organic matter and its biodegradable fraction in drinking water Water Res. 1999, 34, 3247-3257

${ }^{5}$ Amirtharajah, A.; Dennett, K. E.; Studstill, A. Ferric chloride coagulation for removal of dissolved organic matter and trihalomethane precursors Water Sci. Technol. 1993, 27, 113-121

${ }^{6}$ Mayer, B. K. Efficacy of Enhanced Coagulation and Disinfection for Treatment of Enteric Viruses. Dissertation, Arizona State University: Tempe, AZ, 2008.

${ }^{7}$ Abbaszadegan, M.; Mayer, B. K.; Ryu, H.; Nwachuku, N. Efficacy of removal of CCL viruses under enhanced coagulation conditions Environ. Sci. Technol. 2007, 41, 971-977

${ }^{8}$ Edzwald, J. K.; Tobiason, J. E. Enhanced coagulation: US requirements and a broader view Water Sci. Technol. 1999, 40, 63-70

${ }^{9}$ Xagoraraki, I.; Harrington, G. W.; Assavasilavasukul, P.; Standridge, J. H. Removal of emerging waterborne pathogens and pathogen indicators by pilot-scale conventional treatment J. Am. Water Works Assoc. 2004, $96,102-113$

${ }^{10}$ Gerba, C. P.; Riley, K. R.; Nwachuku, N.; Ryu, H.; Abbaszadegan, M. Removal of Encephalitozoon intestinalis, calicivirus, and coliphages by conventional drinking water treatment J. Environ. Sci. Health 2003, A38, 1259-1268

11]ofre, J.; Olle, E.; Ribas, F.; Vidal, A.; Lucena, F. Potential usefulness of bacteriophages that infect Bacteroides frageilis as model organisms for monitoring virus removal in drinking water treatment plants Appl. Environ. Microbiol. 1995, 61, 3227-3231

Environmental Science \& Technology, Vol 42, No. 18 (September 15, 2008): pg. 6890-6896. DOI. This article is (C American Chemical Society and permission has been granted for this version to appear in e-Publications@Marquette. American Chemical Society does not grant permission for this article to be further copied/distributed or hosted elsewhere without the express permission from American Chemical Society. 
NOT THE PUBLISHED VERSION; this is the author's final, peer-reviewed manuscript. The published version may be accessed by following the link in the citation at the bottom of the page.

${ }^{12}$ USEPA. Drinking Water Contaminant Candidate List and Regulatory Determinations; United States Environmental Protection Agency: Cincinnati, $\mathrm{OH}, 2007$; available at http://www.epa.gov/safewater/ccl/ccl2list.html.

${ }^{13}$ Enders, J. F.; Weller, T. H.; Robbins, F. C. Cultivation of the Lansing strain of poliomyelitis virus in cultures of various human embryonic tissue Science 1949, 109, 85-87

${ }^{14}$ Crittenden, J. C.; Trussell, R. R.; Hand, D. W.; Howe, K. J.; Tchobanoglous, G., Eds. Water Treatment: Principals and Design, 2nd ed.; John Wiley: New York, NY, 2005.

${ }^{15}$ Budd, G. C.; Hess, A. F.; Shorney-Darby, H.; Neemann, J. J.; Spencer, C. M.; Bellamy, J. D.; Hargette, P. H. Coagulation applications for new treatment goals J. Am. Water Works Assoc. 2004, 96, 102-113

${ }^{16}$ Adams, M. H. Bacteriophages; Interscience Publishers: New York, NY, 1959.

${ }^{17}$ Thurston-Enriquez, J. A.; Haas, C. N.; Jacangelo, J.; Riley, K.; Gerba, C. P. Inactivation of feline calicivirus and adenovirus type 40 by UV radiation Appl. Environ. Microbiol. 2003, 69, 577-582

${ }^{18}$ Rodgers, J. L.; Nicewander, W. A. Thirteen ways to look at the correlation coefficient Am. Statistician. 1988, 42, 59-66

${ }^{19}$ Robeck, G. G.; Clark, N. E.; Dostal, K. A. Effectiveness of water treatment processes in virus removal J. Am. Water Works Assoc. 1962, 54, 1275-1292

${ }^{20}$ Rao, V. C.; Symons, J. M.; Ling, A.; Wang, P.; Metcalf, T. G.; Hoff, J. C.; Melnick, J. L. Removal of Hepatitis A viruses and rotavirus by drinking water treatment J. Am. Water Works Assoc 1988, 80, 59-67

${ }^{21}$ Chaudhuri, M.; Engelbrecht, R. S. Removal of viruses from water by chemical coagulation and flocculation J. Am. Water Works Assoc. 1970, 62, 563-567

${ }^{22}$ Dowd, S. E.; Pillai, S. D.; Wang, S.; Corapcioglu, M. Y. Delineating the specific influence of virus isoelectric point and size on virus adsorption and transport through sandy soils Appl. Environ. Microbiol. 1998, 64, 405-410

${ }^{23}$ Schijven, J. F.; Hassanizadeh, S. M.; de Bruin, H. A. M. Column experiments to study nonlinear removal of bacteriophages by passage through saturated dune sand J. Contam. Hydrol. 2002, 58, 243-259

${ }^{24}$ Penrod, S. L.; Olsen, T. M.; Grant, S. B. Deposition kinetics of two viruses in packed beds of quartz granular media Langmuir 1996, 12, 5576-5587

${ }^{25}$ Cohen, J. Statistical Power Analysis for the Behavioral Sciences, 2nd ed.; Lawrence Erlbaum Associates: Hillsdale, NJ, 1988.

Environmental Science \& Technology, Vol 42, No. 18 (September 15, 2008): pg. 6890-6896. DOI. This article is (c) American Chemical Society and permission has been granted for this version to appear in e-Publications@Marquette. American Chemical Society does not grant permission for this article to be further copied/distributed or hosted elsewhere without the express permission from American Chemical Society. 